\title{
"ECONOMIC BELT OF THE SILK ROAD": NEW OPPORTUNITIES AND PROSPECTS FOR MONGOLIA
}

\author{
Ph.D. student Mavidkhaan Baasandulam \\ People's Republic of China, Hunan province, Xiangtan city, School of Business, Hunan University of \\ Science and Technology
}

DOI: https://doi.org/10.31435/rsglobal_ijite/30112019/6797

\section{ARTICLE INFO \\ Received 29 September 2019 \\ Accepted 17 November 2019 \\ Published 30 November 2019}

\section{KEYWORDS}

Asian Infrastructure

Investment Bank,

National Development and

Reform Commission,

Economic corridor,

Mid-term Roadmap for the

Development of Trilateral

Co-operation between China,

Russia and Mongolia,

"One Belt and One Road"

Initiative. \begin{abstract}
Earth is continents, seas, the developing countries, the developed countries, the centers and the borders is the One Belt-One Road initiative. On the other hand, the Sea "Silk Road" is called the "Economic Belt of the Silk Road" as a way of "New Belt and Road" for China's new long-term development strategy. "Silk Road" refers to the ancient land-based commercial trade route that originated in ancient China and connected to Asia, Africa and Europe.

In order to benefit from the "Economic Belt of the Silk Road" initiative, China has partnered with other Asian countries and created two important financial development institutions, the Asian Infrastructure Investment Bank and the Silk Road Fund.

The main objective of the initiative is to create an Eurasian trade economic integration space and cross-border transport corridors, that is, to strengthen the links between government policies and national development strategies along the route, promote international cooperation, and promote the development of joint ventures. For this purpose, the following tasks have been set: 1. Development of regional economic integration method; 2 . Create an integrated transportation design for Asian transportation, connect communication networks, and develop pipeline systems; 3 . Switch back to investment and trade barriers and create a good investment environment; 4. Strengthen national currency; 5. Deepening cooperation in the humanitarian field; 6. Expanding China's exports and domestic power growth will be concentrated in the western provinces (steel, lead, photovoltaic equipment, wind turbines).

The "One Belt and One Road" is a new starting point for China-global relations and human development. Utilize the geographical advantages of Mongolia, China and Russia to increase cross-border trade between Mongolia, Russia and China, creating opportunities for logistics and transportation. China is one of the Mongolia's largest sources of foreign direct investment and is seen as a huge market for Mongolia to provide services and products.

Mongolia hopes to unite its "Steppe Road" initiative with China's "One Belt and One Road" initiative. The goal of the "Steppe Road" initiative aims to expand the Mongolian economy through cross-border transportation, strengthen the road line connecting Russia and China, transform and extend the current railway line in Mongolia, and build oil and gas between Russia and China. The pipeline improves the infrastructure of Mongolia. Mongolia and other Asian countries are actively participating in the "One Belt and One Road" initiative implemented in China to reduce risks and threats and gain new opportunities and advantages in regional cooperation.
\end{abstract}

Citation: Mavidkhaan Baasandulam. (2019) "Economic Belt of the Silk Road": New Opportunities and Prospects for Mongolia. International Journal of Innovative Technologies in Economy. 6(26). doi: 10.31435/rsglobal_ijite/30112019/6797

Copyright: (C) 2019 Mavidkhaan Baasandulam. This is an open-access article distributed under the terms of the Creative Commons Attribution License (CC BY). The use, distribution or reproduction in other forums is permitted, provided the original author(s) or licensor are credited and that the original publication in this journal is cited, in accordance with accepted academic practice. No use, distribution or reproduction is permitted which does not comply with these terms.

Introduction. Today, the world's greatest interest is China's new initiative to revitalize the "Silk Road" of economic forms under modern conditions. This initiative opens up new opportunities for trade, economic and investment cooperation in economic corridor countries, including Mongolia. In addition, in 
order to effectively implement the "One Belt and One Road" initiative, China is preparing to build new development financial institutions such as the Asian Infrastructure Investment Bank and the Silk Road Fund. Funding for these institutions will be used to implement infrastructure projects. The Silk Road Initiative made a significant contribution to the world's exchanges and cultural exchanges from the East to the West, but then declined for a while. Xi Jin Ping, President of the People's Republic of China, announced the "Silk Road" initiative in Astana, capital of Kazakhstan, on September 13, 2013, and announced that it would conduct joint operations with most of the Eurasian countries under the initiative.

The National Development and Reform Commission of the People's Republic of China issued a strategic plan on March 28, 2015, which together established the goals of "Economic Belt of the Silk Road" and the 21st Century "Maritime Silk Road". The principles and framework of the initiative, and listed five areas of cooperation such as policy-connected countries, infrastructure polarity, trade facilitation, financial integration, and increased understanding among citizens.

\section{Range of the "Economic Belt of the Silk Road".}

The "Economic Belt of the Silk Road" will connect Asia, Europe and Africa in five directions:

1. Connect China to Europe through Central Asia and Russia

2. Integrating China into the Middle East through Central Asia

3. Connecting China, East Asia, Southeast Asia and the Indian Ocean

4. Linking China to Europe through the South China Sea and the Indian Ocean

5. Connect China to the South Pacific through the South China Sea

The successful development of the above five areas will enable the Belt and Road to connect international transport, major cities and ports, and create six economic corridors.

The Northern Corridor: China, Mongolia and Russia are connected by dry land, and there is a long history of economic cooperation between the three countries. In September 2014, at the Shanghai Cooperation Organization's independent meeting, the heads of state of the three countries met for the first time to discuss China-Russia, China-Mongolia, Russia-Mongolia, and the tripartite cooperation based on bilateral relations, and determined the nature of this cooperation and range. The three presidents agreed to combine the China's "Economic Belt of the Silk Road", Russia's "Eurasian Land Bridge Reform" and the Mongolian "Steppe Road". For example, strengthen railway and railway connections, construction, improve customs supervision and transportation capacity, increase public transportation, and build a China-Russian economic corridor. Later, in July 2015, the heads of state of the three countries held the second meeting in Ufa, Russia, and approved the Mid-term Roadmap for the Development of Trilateral Co-operation between China, Russia and Mongolia. It consists of two branches: Mongolia and Manzhouli. The corridor from the eastern part of China to Western Europe will reach 14 days, accounting for three times the sea transportation. In 2015, the mass production and transportation of goods from Manzhouli to Moscow reached 12-14 days.

Eurasian New Corridor: Continues 8500 kilometers from the western border of China. By continuing the railway line from Lianyungang and Xinjiang Alashankou to Rotterdam, the Netherlands, it belongs to the railways of Lanzhou and Xinjiang in China. The route runs from Chinese territory to European ports, via Kazakhstan, Russia, Belarus and Poland.

Central and Western Corridor: The corridor runs from Xinjiang to Central Asia and East Asia. It then reached the Mediterranean and the Arabian Peninsula, belonging to several countries in Central Asia; Kazakhstan, Kyrgyzstan, Tajikistan, Uzbekistan, Turkmenistan, Iran and Turkey.

South Corridor: The corridor passes through Myanmar, Bangladesh and India. The center of this direction is the corridor to the Arabian Sea.

China-Pakistan Corridor: From Kashgar, Xinjiang to the Arabian Sea, including roads, railways and oil pipelines.

China-Indian Peninsula Corridor: This corridor contains East Asian countries such as Thailand, Malaysia and Vietnam. (Association of Southeast Asian Nations).

Commodity turnovers of Mongolia with major trading partners. Correlation-regression analysis between the volume of commodity turnovers (Y), the volume of imports (X1) and the volume of exports (X2)

Tab1e 1. China and Mongolia, Russia and Mongolia commodity turnover, import and export data

\begin{tabular}{|c|c|c|}
\hline Year & Russia & China \\
\hline 2014 & $1,610,925.6$ & $6,541,314.7$ \\
\hline 2015 & $1,097,857.9$ & $5,300,061.2$ \\
\hline 2016 & $936,172.2$ & $4,962,782.9$ \\
\hline 2017 & $1,284,922.4$ & $6,720,000.8$ \\
\hline 2018 & $1,796,284.7$ & $8,474,578.5$ \\
\hline
\end{tabular}


Data source: National Statistical Office of Mongolia

As can be seen from the above data, in recent years, the turnover of goods in two giant countries has been growing, but China still has a big impact on the Mongolian economy. In 2014, the total turnover was 8,152,240.3 thousand US dollars, while in 2016 Russia's turnover decreased by $42 \%$ to $936,172.2$ thousand US dollars, and China's turnover decreased by $24.2 \%$ to $4,962,782.9$ thousand US dollars, while the growth in 2018 was $11 \%$ and $29 \%$ respectively.

Correlation regression analysis was performed to determine the linear relationship and correlation between the parameters.

Table 2. China and Mongolia commodity turnover, imports and exports.

\begin{tabular}{|c|c|c|c|}
\hline Year & Import, $X_{1}$ & Export, $X_{2}$ & Trade turnovers, $Y$ \\
\hline 2010 & $970,976.00$ & $2,466,365.50$ & $3,737,341.50$ \\
\hline 2011 & $2,023,881.30$ & $4,439,860.90$ & $6,463,742.20$ \\
\hline 2012 & $1,873,415.00$ & $4,059,720.30$ & $5,927,135.30$ \\
\hline 2013 & $1,822,603.70$ & $3,706,341.00$ & $5,528,944.70$ \\
\hline 2014 & $1,467,915.90$ & $5,073,398.80$ & $6,541,314.70$ \\
\hline 2015 & $1,389,940.60$ & $3,910,120.60$ & $5,300,061.20$ \\
\hline 2016 & $1,061,163.27$ & $3,901,619.60$ & $4,962,782.87$ \\
\hline 2017 & $1,412,562.00$ & $5,307,438.84$ & $6,720,000.84$ \\
\hline 2018 & $1,969,050.20$ & $6,505,528.30$ & $8,474,578.50$ \\
\hline
\end{tabular}

Data source: National Statistical Office of Mongolia

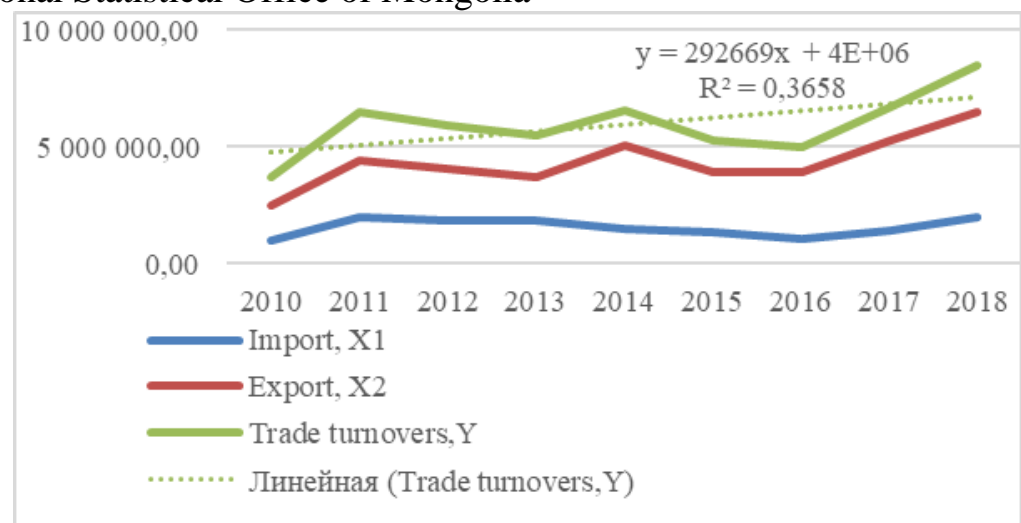

Fig1. China and Mongolia commodity turnover, import and export analysis

As a result of the construction of the correlation matrix obtain the following data (tab. 3).

Table 3. Correlation matrix

\begin{tabular}{|c|c|c|c|}
\hline & Trade turnovers, $\mathrm{Y}$ & Import, $\mathrm{X}_{1}$ & Export, $\mathrm{X}_{2}$ \\
\hline Trade turnovers, $\mathrm{Y}$ & 1 & & \\
\hline Import, $\mathrm{X}_{1}$ & 0.523641705 & 1 & \\
\hline Export, $\mathrm{X}_{2}$ & 0.703093128 & 0.972147898 & 1 \\
\hline
\end{tabular}

Data on regression analysis for commodity turnover, export and import are presented in tab. 4.

Table 4. Regression analysis for commodity turnover, export and import

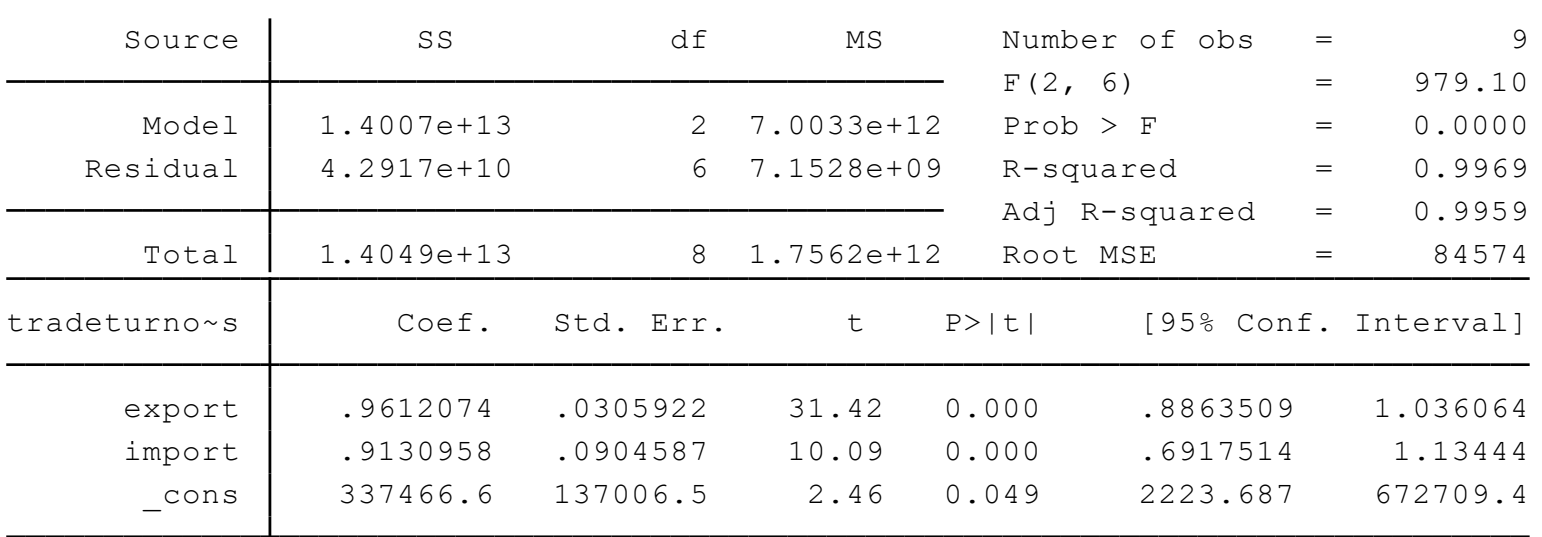


As a result of the solutions of the equation, the following parameters were obtained:

$$
\begin{aligned}
& \mathrm{Y}=\beta_{0}+\beta_{1} * \mathrm{X}_{1}+\beta_{2} * \mathrm{X}_{2}+\varepsilon \\
& \mathrm{Y}=337466.6+0.96 \mathrm{X}_{1}+0.91 * \mathrm{X}_{2}
\end{aligned}
$$

Integration of the obtained parameters should be:

$\beta_{0}=337465.8-$ the conditional beginning of a meaningful interpretation is not subject to;

$\beta_{1}=0.96$ - coefficient of pure regression at the first factor;

$\beta_{2}=0.91$ - pure regression coefficient for the second factor.

The coefficient of multiple correllation is 1 , it indicates that the connection is very strong.

New opportunities for the construction of China-Mongolia-Russia corridor

- China-Mongolia comprehensive strategic partnership opportunity

- In August 2014, Chinese President Xi Jin Ping paid a state visit to Mongolia. The leaders of the two countries signed a joint declaration on comprehensive development of strategic partnership, which brought the two countries into a new stage of development. The declaration states: "Infrastructure construction, such as China, Mongolian railway, highway, port, coal, electricity, petroleum, chemical, copper, iron, uranium, aluminum ore, automotive industry, real estate and light industry, accelerated cooperation mines and mineral investment The project and all aspects improve the quality and quantity of bilateral actual cooperation". Mongolia has abundant mineral resources. It has only established 5 billion tons of coal and 150 million tons of oil resources in the Eastern Province, and Mongolia has the purpose of joining the China, North Korea, South Korea and Japan markets through the "Rashaant- Choibalsan" railway. The economic cooperation between China and Mongolia's comprehensive strategic partnership aims at the development of the mining industry, infrastructure development and financial development, and promotes mutually beneficial cooperation.

- Opportunities under the "One Belt and One Road" Initiative

- In 2013, China launched the "One Belt and One Road" strategy, and in 2014 established the "Silk Road Fund" and "Asian Infrastructure Investment Bank", and in 2015 the "One Belt and One Road" facility entered a realistic stage. State Councilor Yang Jie Chi said in 2014 that China will import 10 trillion US dollars of goods and invest 500 billion US dollars abroad. 500 million Chinese tourists will travel abroad. This will benefit neighboring countries and countries along the Silk Road. It is said that China will strengthen cooperation in eight areas along the "One Belt and One Road", including infrastructure cooperation. Therefore, Mongolia is an important neighbor of China's north, and an important part of the main tunnel of the China-Mongolia corridor has created an unprecedented opportunity for railway construction.

- Mongolian “Steppe Road” Facilities Opportunities

- Based on the geographical advantages of Europe and Asia and the "One Belt and One Road" Initiative, Mongolia strategically proposed the "Steppe Road" Strategy based on transit trade. The "Steppe road" consists of five projects that require $\$ 50$ billion in investment. It includes $997 \mathrm{~km}$ of expressways connecting China and Russia, $1,100 \mathrm{~km}$ of transmission lines, expansion of Mongolian railways, and natural gas and natural gas pipelines. The implementation of the plan by the Mongolian government is expected to attract significant investment, increase production and increase Mongolia's energy and mining potential. According to preliminary estimates, Mongolia will receive 200 billion MNT from China's natural gas and oil pipelines by 2020. Therefore, the development strategies of China and Mongolia are interrelated and complementary. If Mongolia urgently needs infrastructure construction, China has the advantages of foreign exchange, technology and labor, and it is also very effective for the economic development of the two countries.

- Construction opportunities in China-Mongolia-Russia economic corridor

Chinese President Xi Jin Ping emphasized that China's development strategy should be coordinated to promote the development of regional economic cooperation. This reflects China's significance for regional economic development. The presidents of the three countries approved the "China-Mongolia-Russia Tripartite Cooperation Roadmap". Relevant organizations of the three countries approved the "Memorandum of Understanding on the China-Mongolia-Russia Economic Corridor Plan", "Cooperation Memorandum of Customs of the Three Countries to Create Favorable Conditions for the Development of the Three Countries", and "General Agreement on the Development and Cooperation of Border Ports of the Three Countries". 
Historically, Russia's share on Mongolian railways has reached almost 50 percent. Therefore, considering Russia's legal constraints on Mongolian railways, it is best to build the Rashaant Choibalsan railway within the scale of bilateral cooperation between China and Mongolia and Russia and Mongolia. The construction will bring precious development opportunities to the China-Mongolia corridor. These opportunities provide good opportunities for deepening China-Russia economic and trade cooperation and promoting regional economic integration in Northeast Asia.

\section{REFERENCES}

1. "Invest in Mongolia". KPMG in Mongolia, Admon Press, (2016): 2-7

2. T. Ayursaikhan. "The Impact of Foreign Trade on Mongolian Economic Growth". Doctoral thesis (2014): 86-87

3. "Statistical Analysis and Research Guide". Mongolian National Bureau of Statistics, Ulaanbaatar (2007): 2-12

4. D. Shurkuu. "Regarding the friendly relations between Mongolia and China, the political and legal significance of cooperation contract". Academy of Science News, 2014(211) 2-3, http://dx.doi.org/10.5564 /pmas.v54i3.642

5. D. Dulguun. "Foreign Direct Investment and Comparative Research". Institute of Economics, (2019): 2-7

6. D. Davaasukh, D.Tsenddorj. "The Impact of the Chinese Economy on Mongolia". Bank of Mongolia (2012): 1-3

7. J.Gulguu, B.Indra."The Interests of China and Russia in Building the Economic Corridor of China, Mongolia and Russia". International trade Journal, (2018): 82-83

8. B. Byarkhuu. "One Belt One Road and Us". Economic Journal, Ulaanbaatar (2018): 28-29

9. The path, obstacles and strategic analysis of the construction of China-Mongolia-Russia economic corridor, http://www.ite-china.com.cn/zhong-meng-e-jing-ji-zou-lang-jian-she-lu-jing-Zhang-ai-ji-zhan -lue-fen-xi /

10. P. Gansukh. "Business Forum for the Implementation of the Belt and Road Opportunity". General Manager of the Mongolian National Chamber of Commerce and Industry, Business News, Erenhot, China (2017): 6

11. N.Otgonsaikhan. "Preconditions for Mongolia and China to Establish Cross-border Free Zones". Mongolian National University, 2018: 2-5

12. B.Oyun. "Some Issues in Mongolia-China Trade and Economic Cooperation". International trade Journal, 2018 (108): 81-83 